\title{
Modern Movement Migrations: Architecture in Angola and Mozambique (1948-1975)
}

\author{
By Ana Magalhães*
}

\begin{abstract}
The migration and dissemination of architectural models, which may be recognized all along the History of Architecture, accelerated throughout the $20^{\text {th }}$ century, particularly after the Second World War. If on the one hand the geopolitical map as then defined led to a new paradigm of globalization, on the other hand the doctrinal, and often dogmatic, consistency of the architectural thought and production right from the origins of the Modern Movement allowed for the construction of models that facilitated their spreading and acceptance. The concept of flow or exchange associated with the mobility of architects between regions and cultures or with the dissemination of ideas and works is one of the main features of the Modern Movement. It is also under the sign of the idea of flow and exchange that we may understand the architectural production in Angola and Mozambique, both former Portuguese colonies, during the period of the second post-war until their independences in 1975. This paper's intention is, on the one hand, to understand the mechanisms of dissemination of international architectural models and their acceptance in those African countries from a historical point of view, and on the other hand, to analyse the processes of their interpretation in a more orthodox, hybrid or critical meaning. Africa meant for the architects who built there an ideal laboratory for experimenting the modern language, not only by adopting such formal vocabulary, but also by testing building and geography and tropical climate adaptation. At the same time, it is necessary to consider how such idea of modernity and progress was developed within the framework of a colonial society and led to an ideological paradox: how was the assertion of democracy that is present in the genesis of the Modern Movement reconciled with the colonial ideology?
\end{abstract}

\section{Introduction}

The migration and dissemination of architectural models, which may be recognized all along the History of Architecture, accelerated throughout the $20^{\text {th }}$ century, particularly after the Second World War. If on the one hand the geopolitical map as then defined led to a new paradigm of globalization, on the other hand the doctrinal, and often dogmatic, consistency of the architectural thought and production right from the origins of the Modern Movement allowed for the construction of models that facilitated their spreading and acceptance. The concept of flow or exchange associated to the mobility of architects between regions and cultures or to the dissemination of ideas and works is one of the main features of the Modern Movement generally, and the International Style in particular. During the period of the second post-war, the

\footnotetext{
* Assistant Professor /Research Fellow, CITAD/Lusiada University, Portugal.
} 
magazine "L'Architecture d'Aujourd'hui,"1 for instance, conveyed this spirit of globalization, seeking to disseminate an architectural culture and production that were not confined to the European and North-American broadcasting centres, widening the circle to Latin America, Asian countries and even the African continent, accounting not only for some of the most dominant examples within the framework of the "International Style," but also for the regenerating capacity of those models upon absorbing other cultures.

It is also under the sign of the idea of flow and exchange that we may understand the architectural production in Angola and Mozambique, both former Portuguese colonies, during the period of the second post-war until their independences in 1975.

Within the framework of architectural production in Angola and Mozambique, regardless of the specific circumstances in these two territories, of the different periods of time corresponding to the development of the works or of the specific interpretation of each author, there is a remarkable absorption of the models conveyed by Le Corbusier's work and doctrine seasoned with the lexicon and plasticity of Brazilian modern architecture. But, as maintained by Dennis Sharp, the dissemination of modern architecture was not monolithic and did not result in a mere cloning operation. ${ }^{2}$ Africa meant for those architects who built there an ideal laboratory for experimenting the modern language, not only by adopting such formal vocabulary, but also by testing building and geography and tropical climate adaptation. At the same time, it is necessary to consider how such idea of modernity and progress was developed within the framework of a colonial society and led to an ideological paradox: how was the assertion of democracy that is present in the genesis of the Modern Movement reconciled with the colonial ideology? ${ }^{3}$

\section{Ideological Contradictions: Tropical, Colonial and Modern}

The concept of tropical architecture may be read in various ways. In its usual definition, it means an architecture that is fit for the tropical climate, where the building is designed by observing the climate's and the site's specific conditions. Therefore, it takes into account objective criteria, such as location, space and programme organisation in accordance with the best exposure to

1. The magazine L'Architecture d'Aujourd'hui dedicates, for instance, some of its thematic issues to the miscegenation of the Modern works in different geographical contexts such as "Constructions en Pays Chauds" (L'Architecture d'Aujourd'hui, no 67-68, August September 1956. Paris), presenting works designed for the broad spectrum of tropical geography or "Afrique Noire" dedicated to francophone African countries.

2. Dennis Sharp, "Registering the Diaspora of Modern Architecture," in DOCOMOMO - The Modern Movement in Architecture (ed.) Dennis Sharp and Catherine Cooke. Rotterdam: 010 Publishers, 2000.

3. This theme was developed in the Phd thesis: Ana Magalhães, Migrações do Moderno: Arquitectura na diáspora- Angola e Moçambique (1948-1975). PhD diss. (Universidade Lusíada de Lisboa, 2015). 
the sunlight or the winds, using fixed or mobile devices for shade or soil and roof sealants in accordance with the rainfall. Such criteria were obviously watched in accordance with the specific conditions of tropical sub-regions with a dryer or more humid climate.

As a general rule, the formal language of the Modern Movement's architecture, particularly through the Corbusian work and the Brazilian (as well as the Latin-American) architecture disseminated during the second post-war, has easily and enthusiastically incorporated this new vocabulary applied to the specific conditions of the response to the tropical climate. In addition to the nature of a construction based on scientific parameters, tropical architecture acquires an aesthetic meaning.

What we see, quite often, is a phenomenon of "tropicalization" of the architectural language in and outside the tropics, where the built work sometimes obeys rather aesthetic criteria than strict science. But, while this "tropicalization" effect may fall within the framework of the global mass influence and homogenization of modern architecture during this period, one may see, at the same time, a convergence on local cultures and identities through a reinterpretation of native elements and traditional techniques, the outcome of which is, in its turn, also disseminated on a large scale. Good examples of this are the Chandigarh and Ahmedabad projects, where Le Corbusier crossed his language with Indian native culture and geography and re-invents one of his most expressive words: the "brise-soleil."

At the same time, the meaning of tropical architecture also observes readings of an ideological, or even political, nature. The Indian Prime Minister Jawaharlal Nehru (1889-1964), for instance, who had invited a large international team led by Le Corbusier (1887-1965) to design Chandigarh, the future capital of the Punjab, more than upholding modern architecture, would rather use the term tropical architecture, aiming at the specific conditions of the place, the society and the climate, and defined it as the antithesis of colonial architecture. ${ }^{4}$ As a general rule, immediately after the Second World War, the agendas of the largest colonising powers placed their wagers, through their overseas urban planning offices, on public infrastructures investment policies (of which the school facilities programme is an example), and at the same time, on a specific architecture for the tropics (of which the studies carried out by M. Fry and J. Drew ${ }^{5}$ or the Architectural Association's pioneering course on Tropical Architecture ${ }^{6}$ are good examples). It is interesting to see that, in spite of the substantial ideological differences between the

4. Vandana Baweja, A Pre-history of Green Architecture: Otto Kenigsberger and the tropical architecture. From princely Mysore to post-colonial London. PhD diss. (University of Michigan, 2008), 119-120.

5. Maxwell Fry and Jane Drew, Tropical Architecture in Dry and Humid Zones (London: William Clowes and Sons, 1964). Maxwell Fry (1899-1987) | Jane Drew (1911-1996).

6. "The Department of Tropical Architecture began in 1955 under Maxwell Fry, with James Cubbitt on the staff, and was subsequently taken over by Otto Koenigsberger; the unit went on to become a unique and extremely important department with an international reputation - lasting until Koenigsberger's resignation and its closure in 1970." https://www. aaschool.ac.uk/AASCHOOL/LIBRARY/aahistory.php. 
European States, their investment programmes had a similar template, were it under a neo-colonial viewpoint, as in the case of democratic states such as France or England, but also in the framework of a colonial incentive, as in the case of Portugal. $^{7}$

At the same time, it is important to underline the relationship between the aesthetic project of the Modern Movement understood in the Western sense and the modernization of these overseas, African or Asian territories. If, on the one hand, these territories functioned as laboratories of the modern project, on the other hand, it is necessary to consider that the very idea of alterity, of a cultural, geographic or social nature, allowed to integrate other parameters of identity. As Avermaete explains: "Architects attempted to engage in their projects on colonial ground with the local conditions by synthesising the way of living of the colonised [...] and the project of modernisation into a new and 'other' modernism." The experiments of modern architects in the so-called colonial 'laboratories' therefore played an important role in the critical revision of the modernism and the emergence of post-modernism within architectural discourse. $^{8}$

\section{Dissemination and Reception of International Architectural Models in Lusophone Africa}

After World War II, when Portugal was still living under a dictatorship, anachronistically valuing its empire and its colonies, a number of young architects went to Africa and affirmed a modernity that was far from the State-sanctioned architectural models. Such modernity was translated into freedom in a firmer appropriation of the modern movement codes in an international meaning.

It is permissible to establish that the first sign of flexibility and openness of Portuguese architecture to the forms and principles of international modern architecture was ensured at the $1^{\text {st }}$ National Architecture Congress, in 1948. In Portugal, upon the end of World War II and the democratization of the European States, the strife against the Salazar regime became manifest, leading to the organization of the various oppositions, who believed in a swift fall of the so-called "Estado Novo." The political crisis within the regime forced it to use efficient measures that led to a tougher, more consolidated government and, at the same time, to a growing agitation among the various opposing sectors in the Portuguese society, branding it politically, socially, economically and culturally. A new generation of architects, trained in the Arts Schools of Lisbon and Porto, laid claim to a new social, ethical and

7. It is also important to stress that unlike the majority of these former colonies that were decolonised since the beginning of the 1950's until the mid 1960's, the African lusophone colonies only became independent in 1975, as one of the fundamental consequences of the 1974's Portuguese Revolution that put an end to the previous dictatorial regime.

8. Tom Avermaete, Serhat Karakayali and Marion Von Osten (ed.), Colonial modern: aesthetics of the past rebellion for the future (London: Black Dog, 2010), 10. 
political consciousness. If, on the one hand, they claimed a new vision of reality, on the other hand, they tried to theorize and reinforce an idea of architecture, international and orthodox, according to the premises of the Modern Movement.

The diaspora of the Portuguese architects who, during the 50s and 60s, lived and worked in the Portuguese overseas territories was caused by personal factors with various origins - their birthplace, a family presence, political reasons or merely the ambition of new work prospects - and, in a way as well, fostered by the development policies for the colonies of the "Estado Novo." Upon the outcome of the $1^{\text {st }}$ National Congress of Architecture held in 1948, these newly-trained architects set out to the overseas territories with a clear prospect of the possibility of applying the modern vocabulary in a less restrictive way.

In order to understand the architectural production in the African territories, it is also important to underline the significance of the training supplement "away from home", particularly in the case of the experience acquired as trainee in Le Corbusier's ateliers by, for instance, Vasco Vieira da Costa (1911-1982) or Fernão Simões de Carvalho (1929-), who simultaneously studies urban planning in Paris, or else Paulo Melo Sampaio (1926-1968), who studied urban planning in Milan. In this internationalization context, an architect stands out: Pancho Miranda Guedes (1925-2015), an exceptional figure, not only due to his academic training in South Africa, which will make him establish strong ties to the Anglo-Saxon culture, but also due to his constant travels (to Europe and Mozambique's neighbouring countries) or his significant presence on some institutional stages of international architecture since the beginning of the $60 \mathrm{~s}$.

Travelling to survey on-site the architectural works that were being made in Europe, the United States or Brazil, for instance, was not yet very frequent among Portuguese architects, particularly the ones who lived in the faraway African overseas territories. But it should be reminded that many architects who lived in Angola and Mozambique, in addition to performing their activity as professionals, conducted activities of a public nature, with technical positions at local municipalities or teaching, which allowed them to enjoy leaves of absence to visit Portugal, and therefore to make study or work visits to Europe. In the case of the architects living in Mozambique, they travelled often to the neighbouring countries or participated in architecture and urban planning congresses or international fairs, particularly in South Africa, the former Rhodesia or Malawi, which allowed them to make contact with their peers as well as with other realities under the point of view of both architectural production and development of urban centres.

In this way, architects were in contact with international designs and works primarily through publications or periodicals, especially the magazine L'Architecture d'Aujourd'hui, the international periodical that was most read amongst Portuguese architects (for most of whom French was their first foreign language), or the magazine Arquitectura, which, during its post Congress period, often published exemplary international architecture works. 


\section{Modern versus Colonial}

In the context of the colonial society, two models of adopting architectural languages co-exist: one model of a more historical or monumental nature, which was present, in particular, in public works produced in Portugal for its overseas territories, and the predominance of a formal modern vocabulary, of an international nature, mainly associated with private initiative. Apparently, these two models are opposed under the ideological viewpoint. But ideologies, even the most dogmatic, are, in themselves, also contradictory. And the production of architecture corresponding to such ideologies is often contradictory as well.

But what one often sees in the architectural production during this period is the paradox in the design development, regardless of their formal model.

In the case of the urban plan for the city of Beira, for instance, based on an urban model that falls within the "Garden-City" models advocated by the GUU, ${ }^{9}$ its authors propose a zoning that, after all, corresponds to the "segregation of the dwellers according to their customs" (a borough for European customs population, a borough for Asian customs population and a native borough), and at the same time they quote the Athens Charter, electing three functions as the guidelines of the project: "dwelling, working and entertainment." 11

In this same city, where good examples of modern vocabulary houses were built, the urban plots were drawn and dimensioned taking into account resident employee housing, which, although incorporated in the project, were segregated and less qualified spaces.

Similarly, Vieira da Costa's project "Design of a Satellite City for Luanda" (1948) (Figure 1), applying the modern dogmas to the erection of a colonial town, is surely a paradoxical view, as he wrote on his final diploma project: "It is therefore incumbent on the European man to create in the native the need for comfort and a higher life, thus inciting him to the work that will lead him to settle down, and this will facilitate a more stable workmanship. The positioning of the houses and the location of native boroughs are the two main constituents that should govern the composition of the plan of a colonial town (...). In this way, we would rather place native boroughs around the central hub, taking due care to locate it, at all times, toward the lee of European housing areas, which must nevertheless be, at all times, isolated by means of a green screen wide enough to prevent the mosquito from passing over it. As it seems of necessity, under a health and social point of view, native populations should form various scattered groups that will embrace as small satellites the European hub, and so each sector of this hub will be served by a native group. In this way, we will shorten the

9. Gabinete de Urbanização do Ultramar - Overseas Urban Office.

10. Câmara Municipal Beira, Cidade da Beira - projecto de Urbanização - memória justificativa (Beira: Empresa Moderna, 1951), 95.

11. Ibid, 11. 
distance to be covered between workplace and residence."12 It should be noted, however, that this hierarchical social organization model is based perhaps more on Le Corbusier's 1922 "Ville Contemporaine" project than on the Athens Charter postulates, in which the city was already thought for a "classless" society.

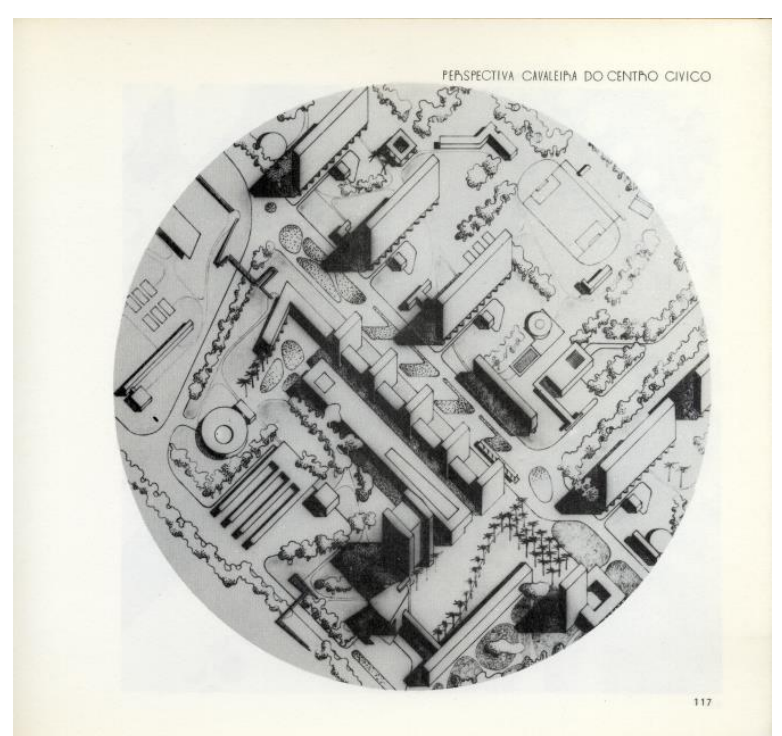

Figure 1. Vasco Vieira da Costa - "Luanda Sathelite Plan $n^{\circ}$ 3." 1948. Civic Center Center Detail and Housing Units

Source: Costa, 1984, p. 117.

Vasco Viera da Costa, while his training was still fresh, between the modern paradigm and the colonial condition, asserted that it is "absolutely necessary to be colonial in order to be able to be a colonial urban planner."

As a counterpoint, one might stress the exemplary case of Bairro do Prenda (1962-1963, 1965), in Luanda, by Fernão Simões de Carvalho and José Pinto da Cunha (1921-2006), which falls within the neighbourhood unit system proposed under the Luanda Master Plan (1961-1964) that was developed by a team led by the former (Figure 2). Based urban planning models that cross the Corbusian premises and doctrines - from the Athens Charter to Chandigarh's traffic hierarchical system - and the social thinking of the urban planner Robert Auzelle (1913-1983), the Bairro do Prenda project incorporated not only housing (houses and collective structures) with community facilities, but also various social and ethnic groups.

12. Fernando Távora, Revista de Arquitectura (Porto: Faculdade de Arquitectura da Universidade do Porto, 1987), 24.

13. Vasco Vieira da Costa, Luanda - Cidade Satélite $n^{\circ} 3$. Concurso para a obtenção do Diploma de Arquitecto, 1984, 13. 


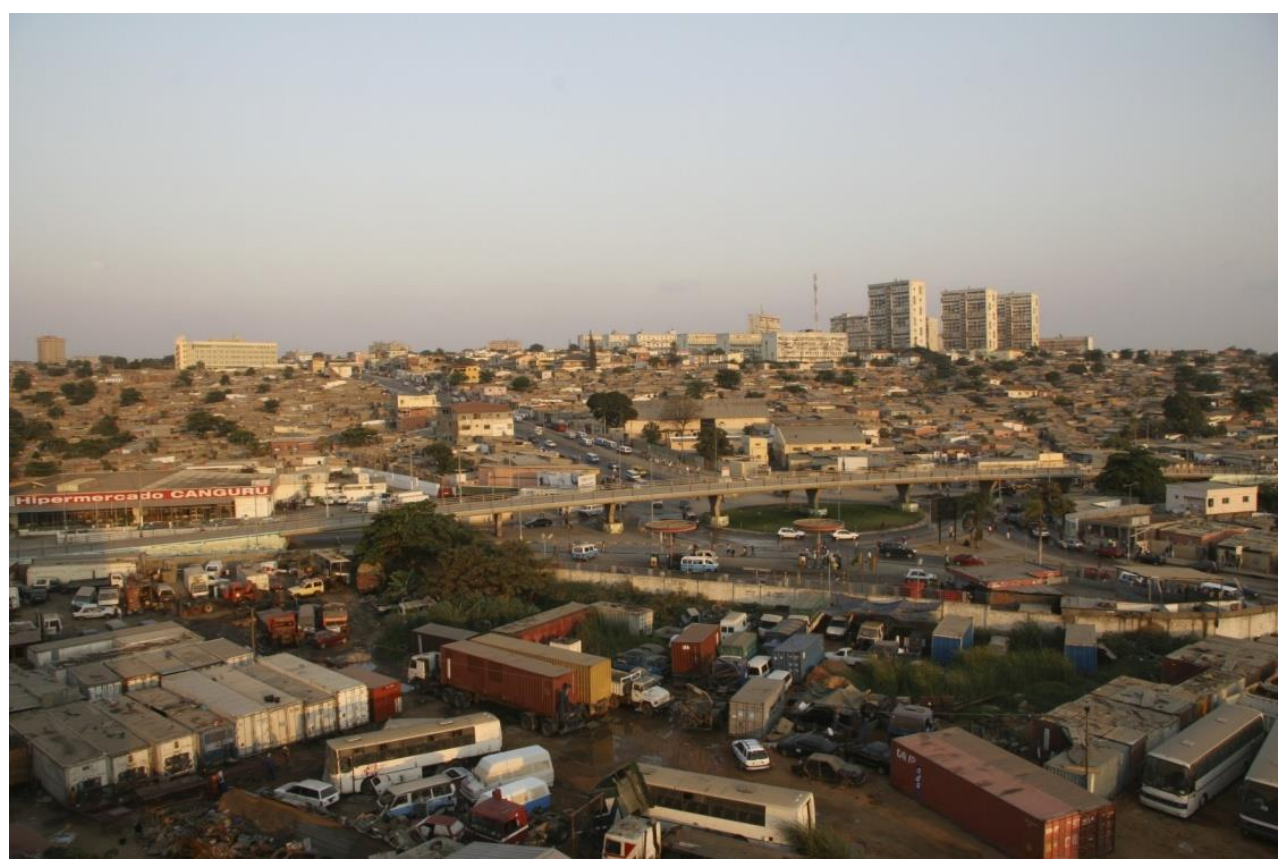

Figure 2. Prenda Neighborhood, Luanda, Angola (1963-1967); Fernão Simões de Carvalho

Source: Inês Gonçalves, 2008 in Magalhães, 2009, p. 71.

\section{Architecture in Angola and Mozambique: A Modern Laboratory}

Regardless of the specific circumstances of those two African territories and the individual interpretations of the authors mentioned, it is possible to observe a common denominator in the developed works and assert an identity belonging to the various genealogies of the models conveyed by the Modern Movement. Such identity is clearly shown in the adoption of a formal and spatial vocabulary composed of a combination of invariable features. For these architects the chance to build in the African territory was the ideal laboratory, not only as to the more orthodox or more hybrid interpretation of the modern vocabulary, but also as to the construction techniques and adaptation to geography and climate. The specific nature of this architectural production was possible due to a strong mastering of the technical and structural capabilities of reinforced concrete as a standard, industrial production constituent, as well as due to its expressive qualities as regards plasticity or texture. As a good example of this we might mention the brise-soleil or the multi-drawing grids, which favour not only the shading but also the natural ventilation of the buildings in tropical climates. It is within this framework, between testing the modern lexicon and response to the tropical climate that the grid and the brise-soleil are exhaustively employed in the architectures in African territory: from the common, anonymous building to the highbrowed, author building (Figures 3 and 4). 


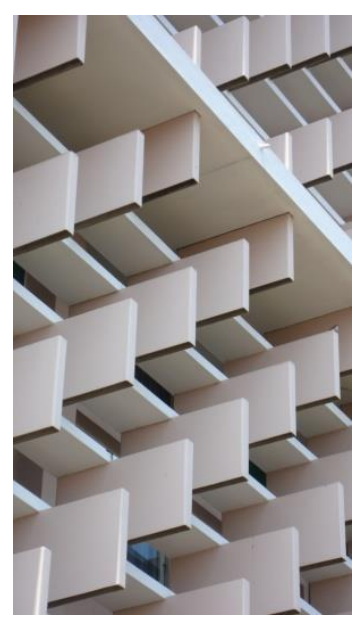

Figure 3. Maristas School, Beira, Mozambique (1959)- Francisco José de Castro. Detail Brise-soleil

Source: Ana Magalhães, 2008.

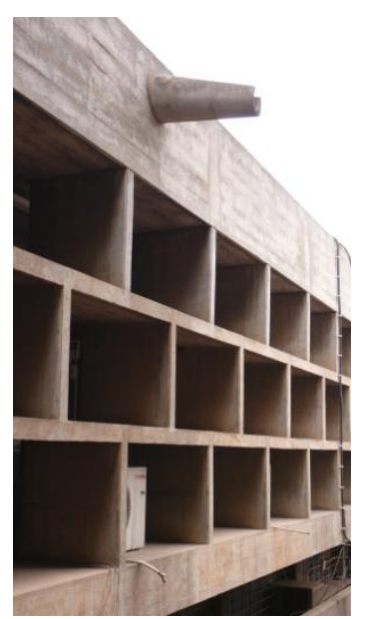

Figure 4. Rádio Nacional de Angola, Luanda, Angola (1963-1967)- Fernão Simões de Carvalho. Detail Brise-soleil

Source: Ana Magalhães, 2008.

The search for the plastic expression and spatial qualification, the employment of colour, exhaustively studied in the Salubra ${ }^{14}$ and employed in Le Corbusier's post-war projects, as well as the search for the total work of art in the sense of integration or contamination between art and architecture, coming close to the Corbusian concept of "espace indicible," 15 all these are elements that cross over such African works. On the one hand, bright, saturated colours will be employed in many works in Angola and Mozambique, which, although not directly referenced in the Salubra catalogue, visually report to Le Corbusier's of the end of the $40 \mathrm{~s}$ and all along the 50s. On

14. Le Corbusier, Salubra, Claviers de Couleur (2ème série) (Zurich: Éditions Salubra, 1959).

15. Le Corbusier, “L'Espace Indicible," L'Architecture d'Aujourd'hui $n^{o}$ special Art, Boulogne, (January 1946): 9-17. 
surfaces (such as floors, internal walls or external façades), colour could be applied through painting or by means of cladding materials, such as glazed mosaics or tiles (Figure 5).

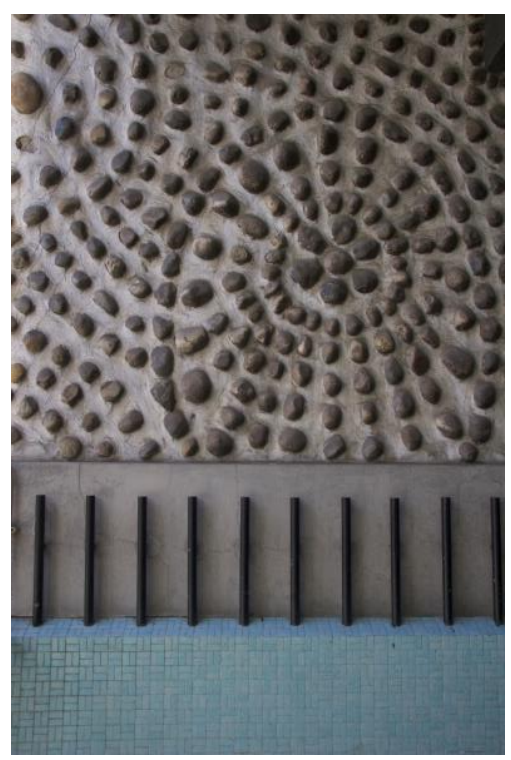

Figure 5. Abreu, Santos e Rocha Building, Maputo, Mozambique (1953)Pancho Miranda Guedes. Detail.

Source: Inês Gonçalves, 2008 in Magalhães, 2009, p. 71.

In the extensive and heterogeneous work of Pancho Miranda Guedes in Maputo, for instance, the total work dimension, i.e. architecture and painting and/or sculpture all at the same time, is expressively achieved. But there is neither integration nor disciplinary autonomy; there is rather a work and an author (or his other self). For Pancho Guedes, the process of creation of his work admits all sorts of ways, a lot of contaminations and metamorphoses from the various artistic areas in space and time: "Drawing, painting, sculpture and architecture are a single language with many words and an endless alphabet. The words they lend one another area ideas, dreams and gestures Lines, shapes, colours, volumes and time." ${ }^{16}$ An admirer of the great Mexican mural painters, such as José Orozco (1883-1949) or Diego Rivera (18861957), Pancho Guedes proposes, in most of his buildings, the creation of murals that are drawn by him and executed with lasting, resistant materials. ${ }^{17}$

On the Abreu, Santos e Rocha building (1953), a huge mural made of small pebbles finishes off one of the volumes of the building, by means of a perforation effect that formalizes African arts and crafts imagery (Figure 6). In the "Dragon" building, it is the mural itself, located in the entrance gallery, really visible from the street, that gives the building its name. This mural is

16. Pedro Guedes, Pancho Guedes: Vitruvius Mozambicanus (Lisboa: Museu Colecção Berardo, 2009), 39.

17. Ibid, 65. "[...] I convinced the clients that the use of natural resistant materials (neither plastered nor painted) on well-visible vertical surfaces was a good solution under the economic viewpoint." 
executed as a reinterpretation of the "calçada à portuguesa" (Portuguese stone paving), once again stressing the architect's concerns as to durability of the materials and exploration of new (old) textures. ${ }^{18}$

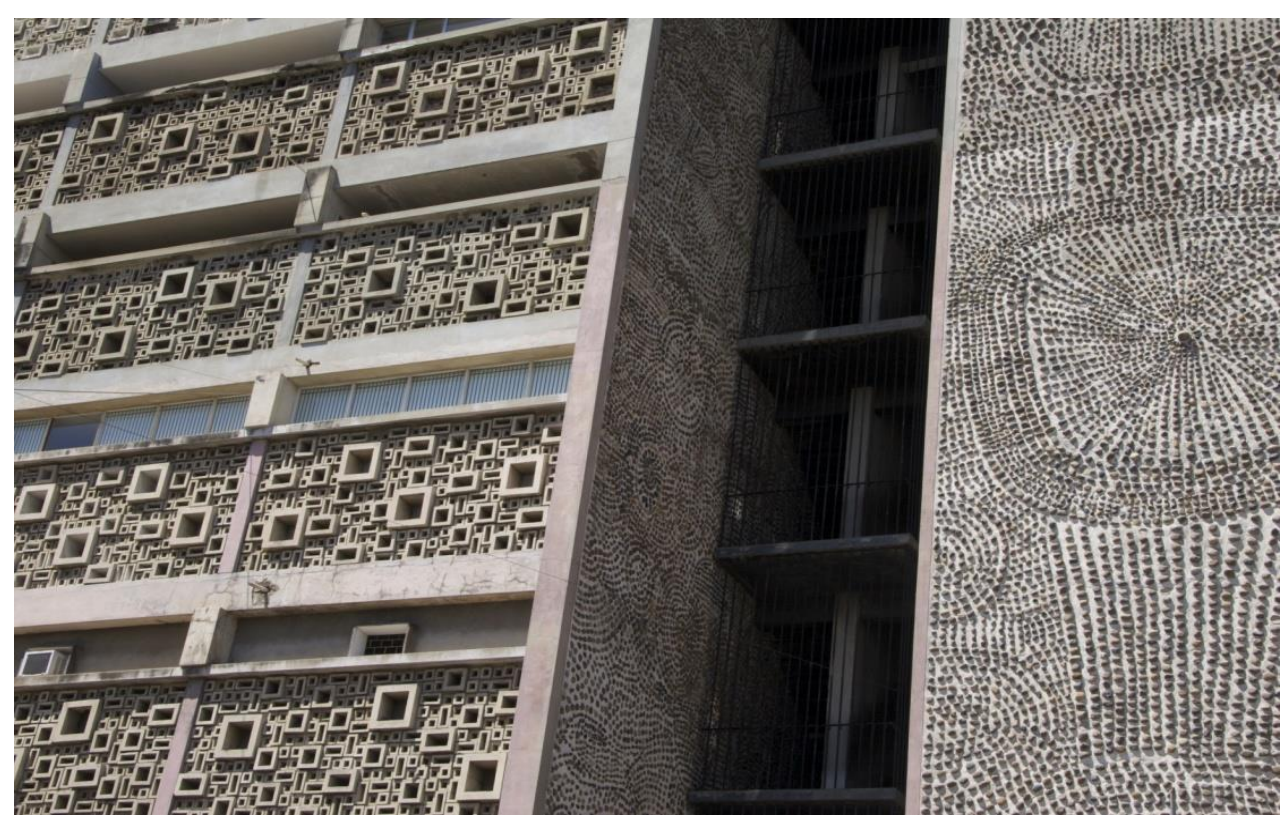

Figure 6. Abreu, Santos e Rocha building, Maputo, Mozambique (1953)Pancho Miranda Guedes. Detail Facade.

Source: Inês Gonçalves, 2008 in Magalhães, 2009, p. 172.

In addition to the murals that are present in so many buildings he authored, with either internal or external presence, having either a more private or a more public, urban dimension, and being more or less conspicuous, such as the Zambi restaurant panel, the top piece of the "Leão que Ri" ("Laughing Lion,") the ceiling of the canopy of the Mann George building, this vocation of an architecture contaminated by the other arts is displayed in the sculptural, pictorial and chromatic nature of the universe of shapes and images that are present in his works.

The African arts and crafts are a few of the keys to decode the extensive work of Pancho Guedes, himself a collector of artefacts from "all over the world, but mostly from Mozambique and Angola"19 and, as already mentioned above, the driving force of the remarkable trajectory of the Mozambican painter Malangatana.

On the other hand, the close cooperation between architects and artists, often using African imagery, has also contributed to the uniqueness of this universe of works. The imagery of the African art and culture became, all

18. Ibid. "Because I am a Portuguese citizen, it seemed to me that the solution would be to resort to the techniques and materials of the pavers who make drawings on the sidewalks and squares of Portugal."

19. Ibid, 165. "These objects remind me that there are other creatures, other ways of life and other forms of expression. They give me a passage to such other worlds." 
along the 60s, one of the most important references of plastic artists residing in Angola and Mozambique (Figure 7).

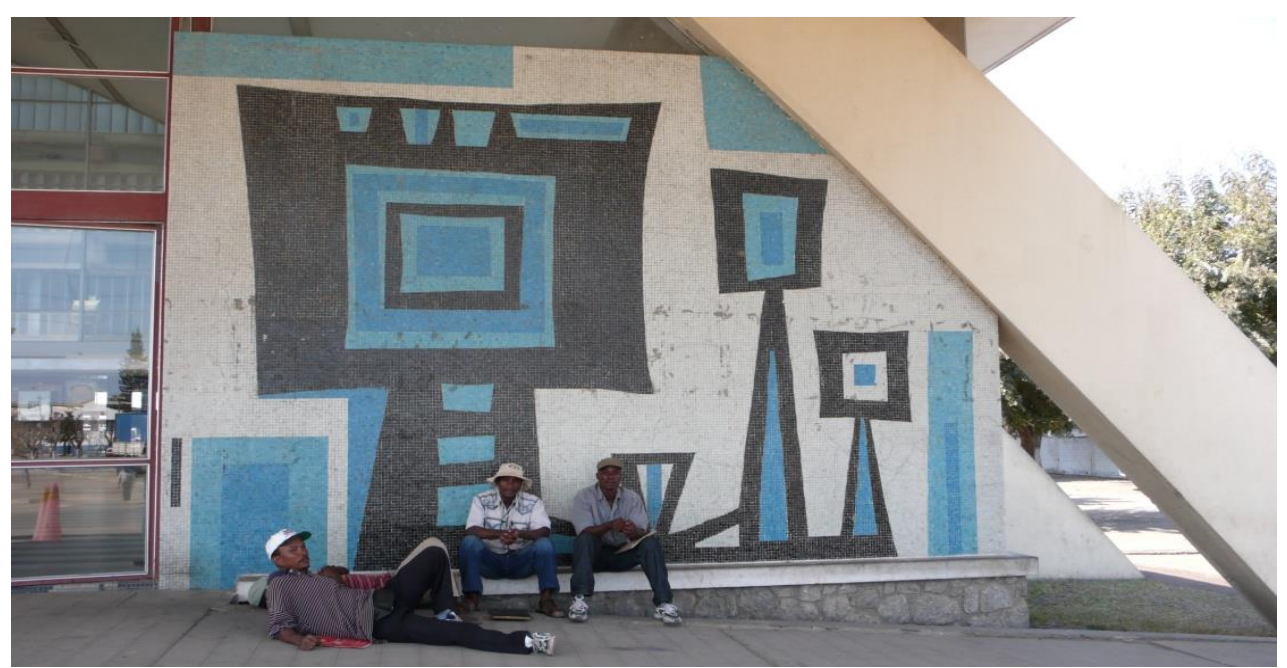

Figure 7. Beira Railway Station, Mozambique (1958-1966) | Mural Jorge Garizo do Carmo (1927-1997)

Source: Ana Magalhães, 2008.

\section{Modern Architecture: From Universal to Local}

In spite of the common template, different genealogies of architectural models and languages may be found in the path of those architects. In the case of Angola, for instance, Vieira da Costa and Simões de Carvalho, both Le Corbusier's disciples, built up their language by reinterpreting the master's references (Figure 8).

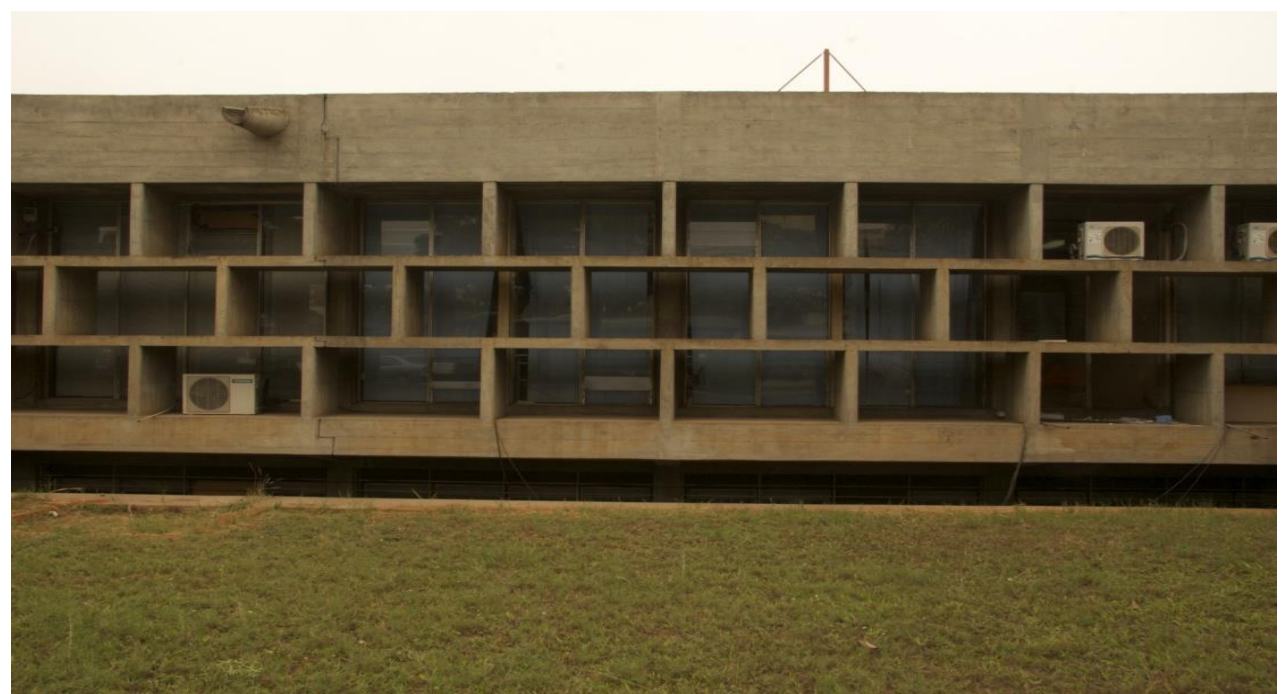

Figure 8. Radio Nacional de Angola, Luanda, Angola (1963-1967)- Fernão Simões de Carvalho

Source: Inês Gonçalves, 2008 in Magalhães, 2009, p. 157. 
In its turn, the influence of Brazilian modern architecture, reminding the work of Oscar Niemeyer (1907-2012) or Affonso Reidy (1909-1964), is obvious in the architecture of the city of Beira, such as the Manga Church (19551957), (Figure 9) by João Garizo do Carmo (1917-1974) or Motel Estoril (1957-1959) by Paulo Sampaio.

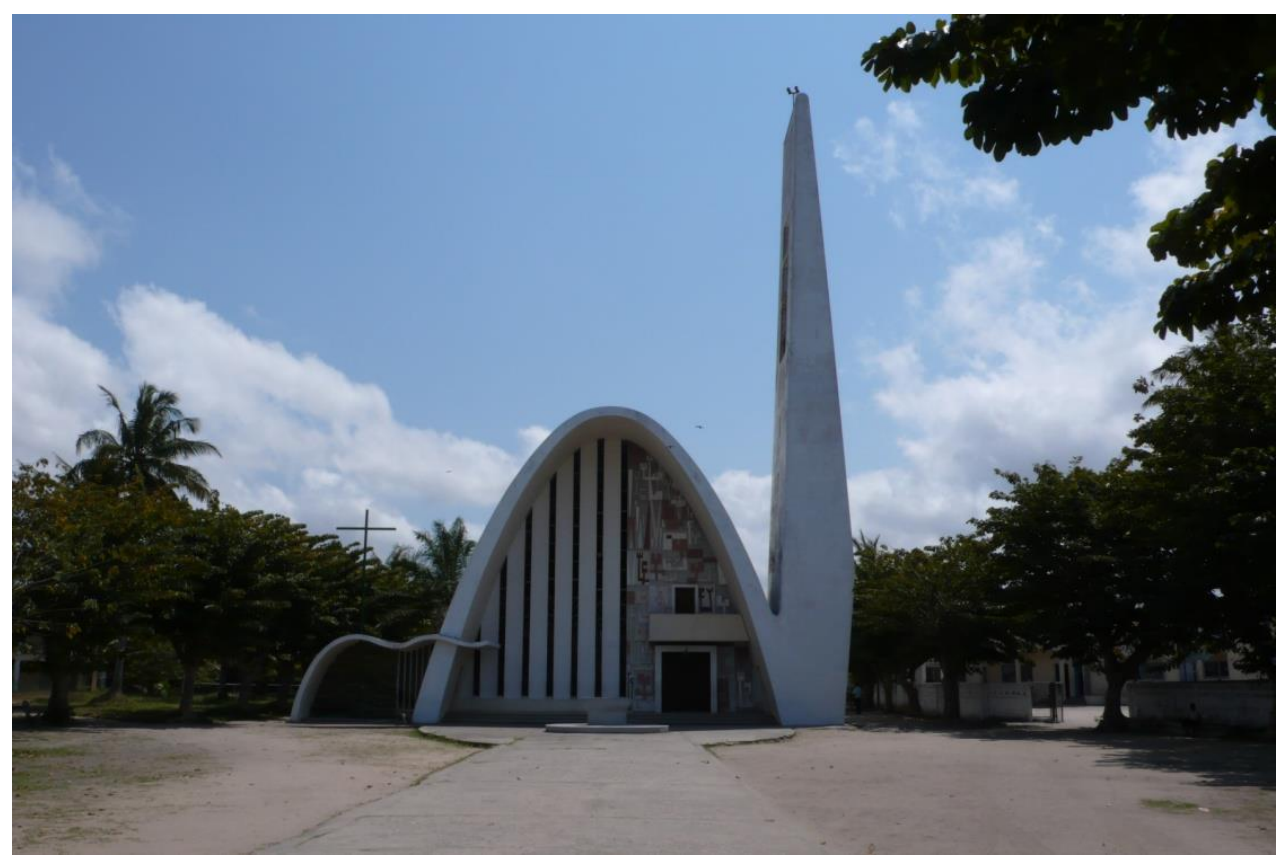

Figure 9. Manga Church, Beira, Mozambique (1955-1957), João Garizo do Carmo

Source: Ana Magalhães, 2008.

There are many projects that, by interpreting their models in a hybrid manner, and sometimes behind time, insist on the modern premises at a time when criticism is felt and new answers are looked for. In the African context, their search was for a less universal and more local answer. Or, as João José Tinoco proposed, they crossed "regional and universal" 20 and "cosmopolitan and native." 21 The heterodox architecture of Pancho Guedes goes far beyond this, and reinvents the modern and announces the post-modern.

The role of private initiative orders in fostering freedom and as a catalyst for the modern project was of the essence. In the case of single houses, for instance, this allowed for testing multiple expressions of the modern vocabulary. The cases of José Pinto da Cunha, in Luanda, or Paulo Melo Sampaio and João Garizo do Carmo, in the city of Beira, should be stressed. In this set of works, tests are common, both in the space structures of the housing typology and in the formal nature, as well as in the way of effectively responding to climate conditions. Having as their common basis the Corbusian proposition

20. João José Tinoco, "Da Arquitectura Moderna em África e o seu panorama em Lourenço Marques," in Capricórnio magazine, no. 2 (September 1958), 6-9.

21. Idem. 
of the "Five Points,",2 those architects sought other references, such as the plasticity of the Brazilian modern architecture, in the case of Beira's architects, or the imagery of "Californian" houses, such those proposed by the "Case Study House Program," 23 in the case of Pinto da Cunha. The house that the architect Pinto da Cunha designed for his family in 1965 is a large parallelepiped volume partially elevated on pilotis. The volumetric clarity of the suspended parallelepiped, the strong interrelationship between interior and exterior, emphasized in the transition spaces that can be seen in the internal courtyard and the balcony that extends the living room or in the space continuity ensured by the transparency obtained from extensive glass panes, the construction details in the drawing of the staircase, furniture or water mirror, all these are a combination of constituents occurring frequently on the designs of Californian houses (Figure 10).
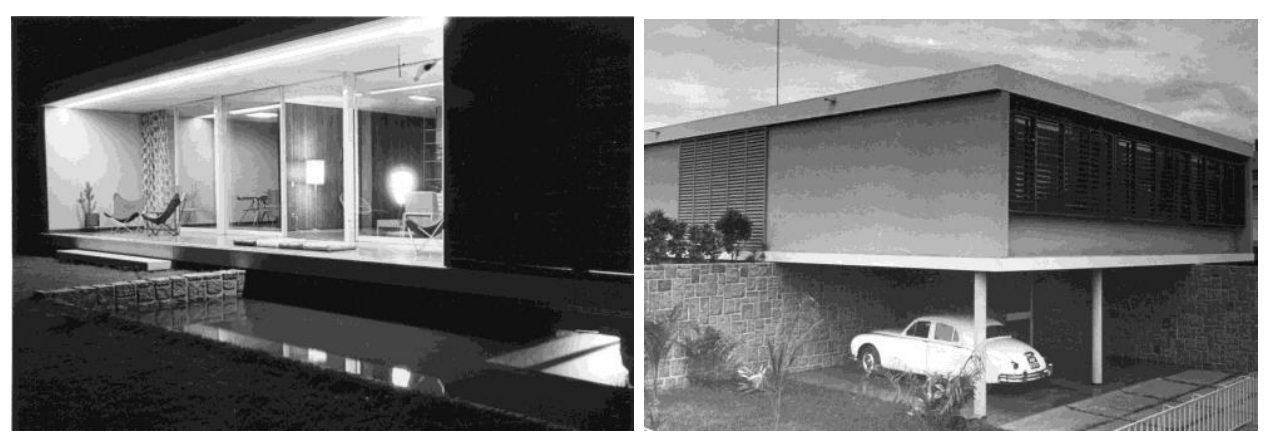

Figure 10. Pinto da Cunha House, Luanda, Angola (c.1965). José Pinto da Cunha

Source: Luisa Cunha Archive.

In a more heterodox sense, Pancho Guedes' extensive work in singlefamily houses in Maputo reveals a reinterpretation of the Corbusian thinking and work, but in this case with irony and eclecticism. This is the case, for instance, of the Matos Ribeiro Twin Houses (1952), where a rationalized space organization contrasts with the insertion of a combination of figurative elements that point to Art Nouveau language or Gaudi's work. Although the articulation of the different floors in the house is made by staircases and ramps reminding Le Corbusier's "promenade architectural," the important point to be stressed is the multiple conjunction of models in the same project, between the functional simplicity that shows that the lessons of the Modern Movement were learnt and the complexity generated by the overlapping (or collage) of more subjective, personal images from multiple origins and times (Figure 11).

22. Alfred Roth (ed.), Zwei Wohnhauser von Le Corbusier and Pierre Jeanneret: Funf Punkte zu einer neuen Architektur (Stuttgart: Akadem Verlag Dr. Fr. Wedekind and Co., 1927) and L'Architecture Vivante ${ }^{\circ} 17,(1927)$.

23. Elisabeth A. T. Smith, Case Study Houses - The Complete CSH Program, 1945-1966 (Taschen, 2009). 


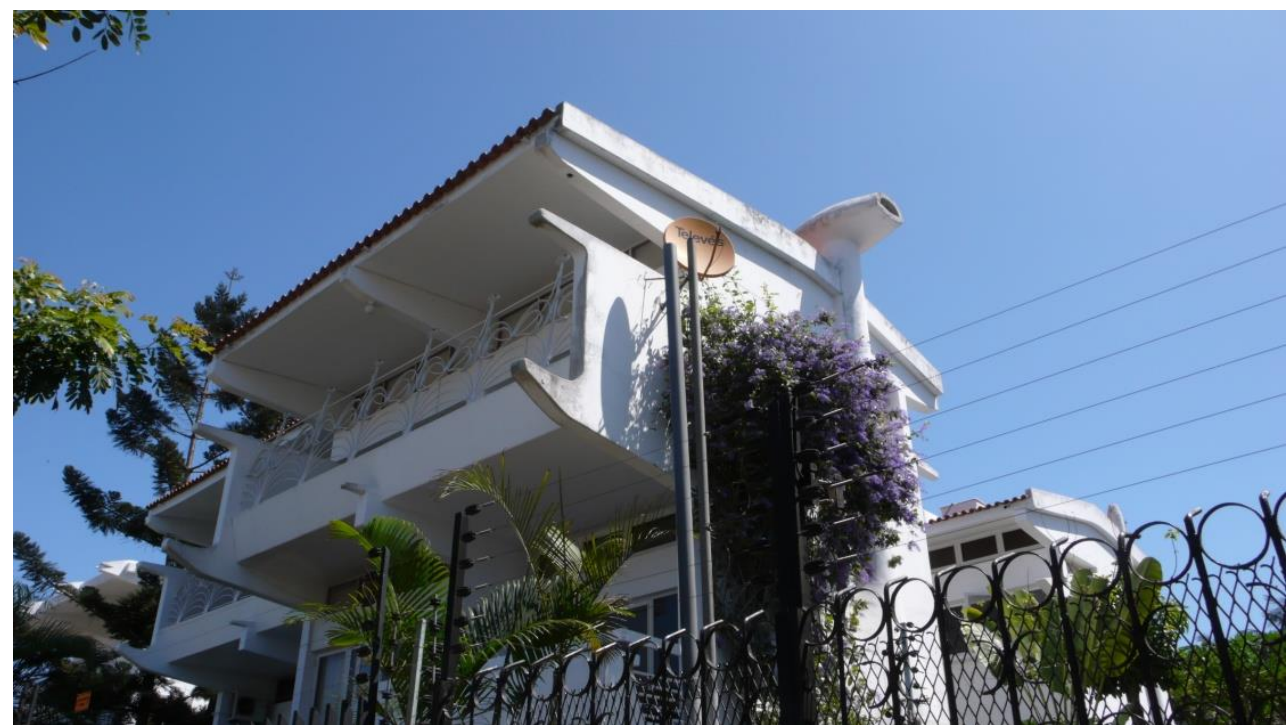

Figure 11. Matos Ribeiro House, Maputo, Mozambique (1952). Pancho Miranda Guedes

Source: Ana Magalhães, 2008.

The progressive urban model of the Marseille Housing Unit (1945-1952) allowed for an intense typological research in the field of collective housing after World War II. The "Unité d'habitation de grandeur conforme" developed as a prototype re-equating the functionalist dimension through the expressionmanifesto of the house as a living machine will allow for a wide experimentation in the study of housing for the masses, by researching new forms of conjunction and internal organization of the dwellings, circulation schemes or space hierarchy. The Housing Unit model, a mixed repeatable block, will be thoroughly exploited, not only in the European reconstruction after the war, but also in other lands and geographies, seeking its adaptation to different climates, cultures and social contexts. But if “(...) as a prototype the Unite was unavoidable, the problem was to transform its fundamental lessons into a more flexible terminology attuned to particular cities, societies and climates."24

The Angolan and Mozambican cities, which predominant model was characterized by the sectorial city having a design inspired by the Garden City, based on a radial and axial composition, with wide avenues and extensive low-density residential areas, favour the single house. However, here and there, particularly in Luanda or Maputo, one can find a few detail plans that fall within the conceptual and formal framework of the urban models based on the Charte d'Athènes and foster the construction of collective housing units.

Such housing buildings addressed to an urban colonial middle class started to be designed at the end of the 50s and are a significant mark of the largest Angolan and Mozambican cities of the 60s. Although in a much lesser size than the Marseille Housing Unit, such buildings are mixed housing,

24. William Curtis, Modern Architecture since 1900 (London: Phaidon, 1999), 443. 
service and shop blocks, which are based on the premises of the reference model and test new housing typologies as appropriate for the tropical climate.

In Maputo, the Tonelli building (1954-1958), designed by Pancho Miranda Guedes (1925-2015), is a housing tower with twelve floors, combining duplex and single apartments, has in the housing unit of the Unité a little of its genesis and consists in "the original human shelf" (Figure 12) as Pancho Guedes stated $^{25}$ or the TAP/Montepio building (1955-1960), by Alberto Soeiro (1917nd.), where the conjunction of housing cells around two external circulation galleries is remarkable. In the city of Lobito, the Universal building (19571961), Francisco Castro Rodrigues (1920-2015) exploits the integration of housing spaces, community spaces and public spaces (Figures 13 and 14). A circulation through an external peripheral gallery, a skillful composition of the housing cell conjunction structure and a rational sense of the internal organization of the dwellings are common denominators of all three projects and reflect not only an appropriate response to the characteristics of the climate but also the colonial society's desire for modernization.

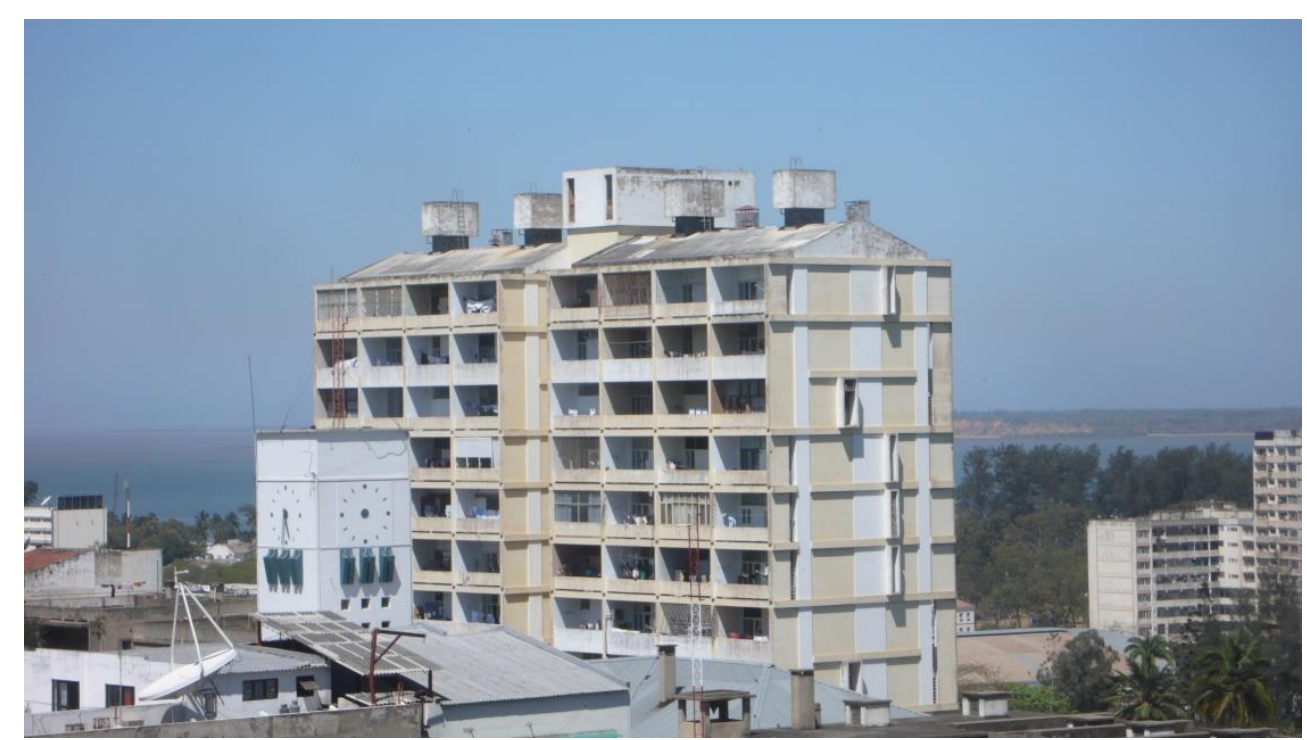

Figure 12. Tonelli building, Maputo, Mozambique (1954-1958)- Pancho Miranda Guedes

Source: Ana Magalhães, 2008.

25. Francesca Ferguson (ed.), S AM 03 Pancho Guedes - An Alternative Modernist (Basel: Christoph Merian Verlag/Swiss Architecture Museum, 2007), 57. 


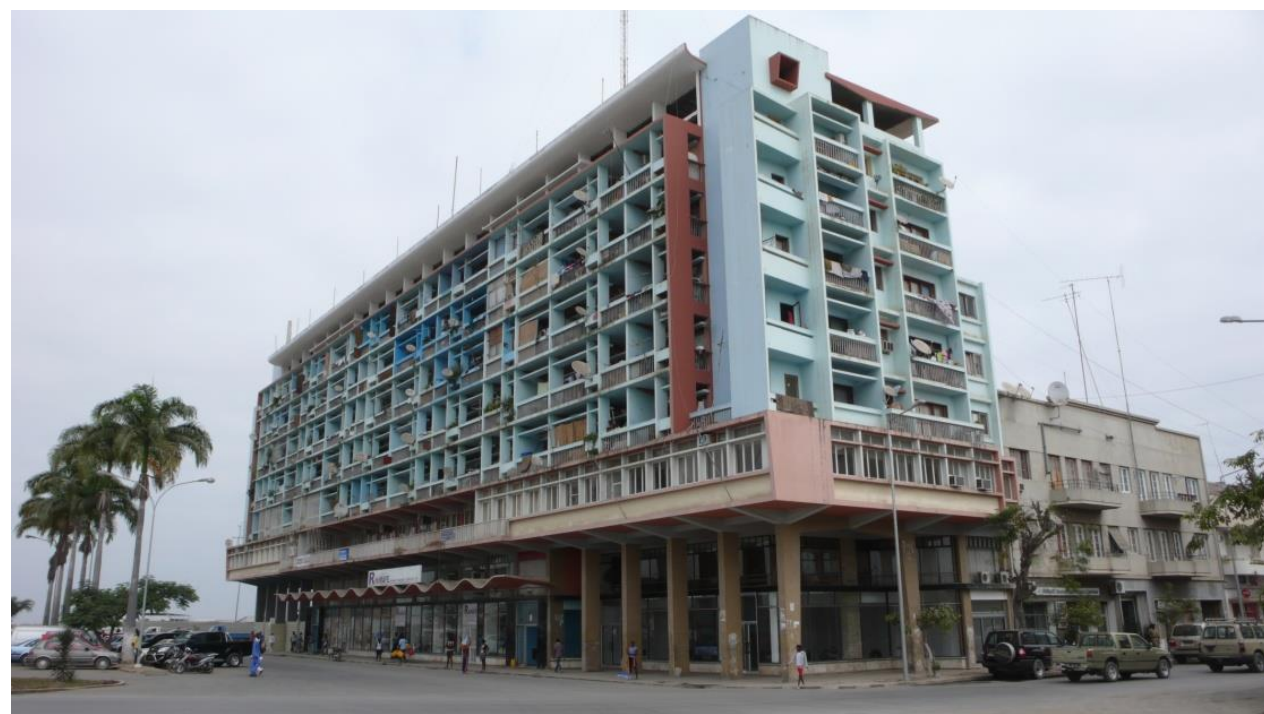

Figure 13. Universal Building, Lobito, Angola (1957-1961) - Francisco Castro Rodrigues

Source: Ana Magalhães, 2008.

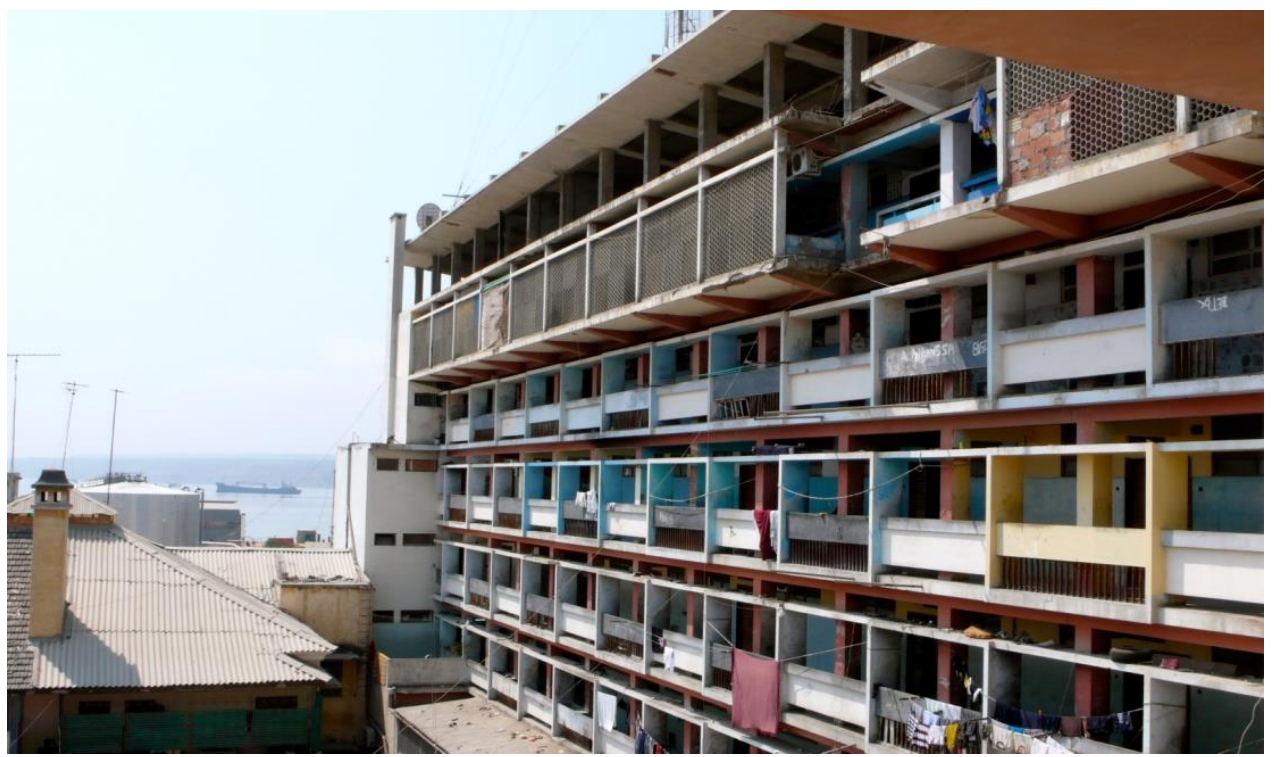

Figure 14. Universal Building, Lobito, Angola (1957-1961) - Francisco Castro Rodrigues

Source: Ana Magalhães, 2008.

Such works, which are the heirs of the Unité and the modern premises, are, however, late examples, developed between the end of the 50s and all along the 60s, at a time when, in Europe, architects were acquiring a critical conscience over the dogmas of the Modern Movement.

Among community facilities of private initiative, the typologies dedicated to culture, tourism and leisure should be highlighted. Unlike the large Government community buildings, often subject to the restrictive conditions of a cultural policy imposed by the regime and because they are intended for more informal functions, these works are ideal for applying freely the modern codes. Hotels, 
clubs, cinemas or theatres are important facilities in settling population, and they express, in an exemplary way, the idea of prosperity and well-being that was felt among the urban middle class of the Portuguese colonies, especially during the period that preceded the toughening of the colonial war (1961-1974). They reflect very well the wish of modernity and progress of this society.

One of the most paradigmatic examples are the open-air movie theatres, the so-called cine-esplanadas. ${ }^{26}$ If the movie theatre symbolically embodied the idea of progress, the architecture of such spaces affirmed its consciousness: the cine-esplanada is cinematographic in itself. Its spatial structures make us experience an "architectural promenade" with long cinema "travellings". These are large-sized buildings, intended for a mass public and seeking a monumental scale like Cine Flamingo in Lobito (Figure 15) and Cine Miramar in Luanda. Their symbolic nature defines them as strategic landmarks in the urban context. The main concern that is common to all these projects is the structural design of the roof or projected roof platform aimed at giving it an expressive form, or else, the significance given to the size and plasticity of the screen. Such plasticity, as well as the textures and color combinations used are a clear reference to the "free form modern" developed by Brazilian architects in the 1940s and 1950s or by Le Corbusier's late works.

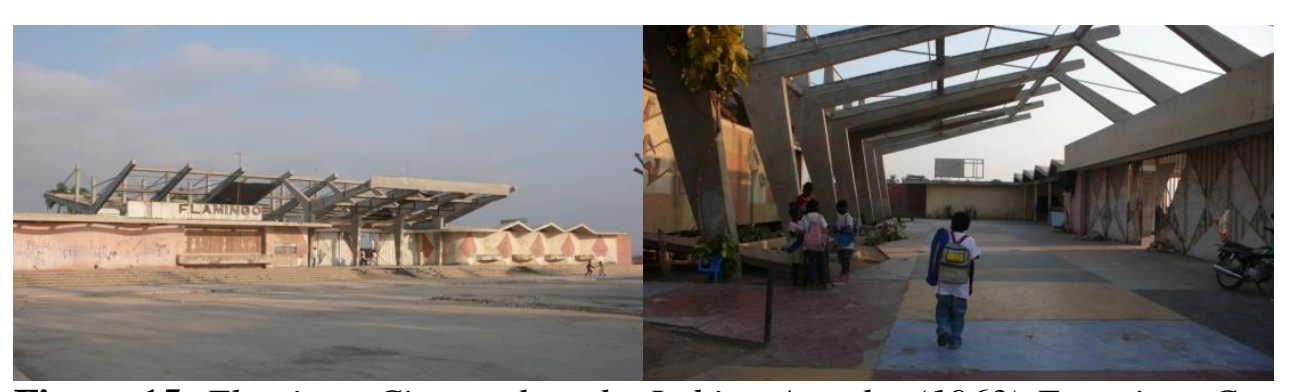

Figure 15. Flamingo Cine-esplanade, Lobito, Angola. (1963) Francisco Castro Rodrigues

Source: Ana Magalhães, 2008.

If private initiative functioned as a catalyst for the modern project, orders from local organizations, from the Church to local authorities, for instance, also made the more traditional and historical nature of public institutions to lose their place in favour of a growing opening for modern languages. In the lineage of the new monumentality ${ }^{27}$ (Figure 16) advocated by post-war modern architects, since the middle of the 1960's, the public work seeks a new relationship with the city and acquires a more symbolic and human sense.

26. Ana Magalhães, Moderno Tropical. Arquitectura em Angola e Moçambique - 19481975 (Lisboa: Edições Tinta da China, 2009); Ana Magalhães, "Modern Architecture in África: open-air movie theathers," in Living Urban Modernity - DOCOMOMO International Conference XI (Mexico City, DOCOMOMO, 2010), 36.

27. Louis I. Kahn, "Monumentality," in Architecture Culture 1943- 1968 - A Documentary Anthology (ed.) Joan Ockman (New York: Rizzoli: Columbia Books of Architecture, 1993), 4754; J. L. Sert, F. Léger and S. GIEDION, "Nine Points on Monumentality," in Architecture Culture 1943- 1968 - A Documentary Anthology (ed.) Joan Ockman (New York: Rizzoli: Columbia Books of Architecture, 1993), 27-30. 


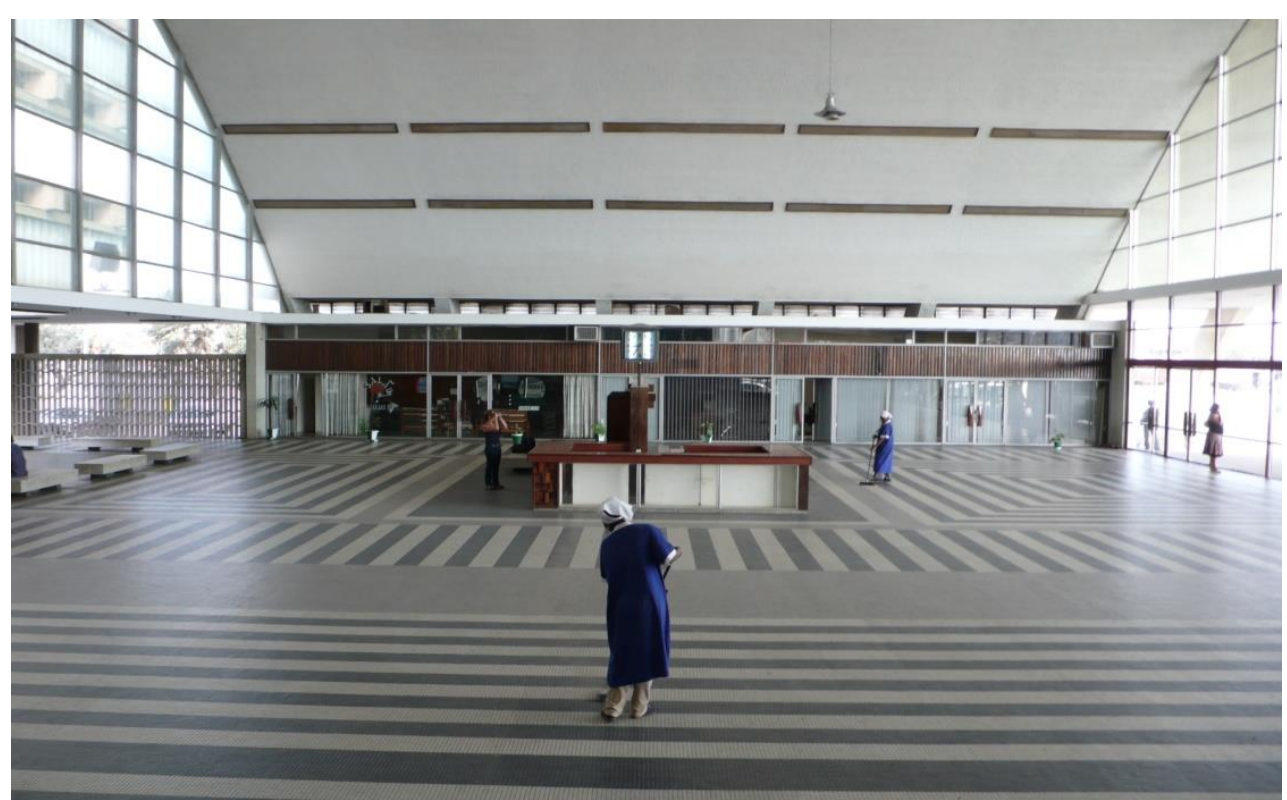

Figures 16. Beira Railway Station, Beira, Mozambique (1958-1966). João Garizo do Carmo, Paulo Melo Sampaio, Francisco José de Castro Source: Ana Magalhães, 2008.

\section{African Modern Architecture Legacy: Identity and Future}

Today, in a post-colonial context, the study of the architectural production in Angola and Mozambique in this specific colonial period raises relevant issues. In addition to the specific inventory and review of the works and their authors, it is essential to consider the value and place of this heritage in the History of Architecture. Firstly, on a broader approach, the idea of its legitimate belonging to the Modern Movement of the second post-war is to be stressed. In spite of the ideological contradictions between the assumptions of democracy and the colonial condition, the identity assertion of these works with the aesthetic and construction values of the Modern Movement architecture is undeniable.

More than forty years after the independences of Angola and Mozambique, identity and heritage issues are still a sensible topic. Far beyond the difficulty of dealing with the memory of this Modern Movement heritage, we are confronted with the History of these countries in transformation: from decolonization to civil war, from the nationalist premises of independence to the search for a new course and a new identity. Only an in-depth knowledge of the cultural and scientific value of this heritage may overcome other priorities, whether of a political or a social or an economic nature. 


\section{Acknowledgments}

This work is financed by national funds by FCT - Foundation for Science and Technology under the Project UID /AUR/4026/2013 and also to CITAD Research Centre for Territory, Architecture and Design.

\section{Bibliography}

Avermaete, Tom, Serhat Karakayali, Serhat and Marion Von Osten (ed.). Colonial modern: aesthetics of the past rebellion for the future. London: Black Dog, 2010.

Baweja, Vandana. A Pre-history of Green Architecture: Otto Kenigsberger and the tropical architecture. From princely Mysore to post-colonial London. Phd Dissertation. University of Michigan, 2008. http://bit.ly/2jeqjFP.

Beira, Câmara Municipal. Cidade da Beira - projecto de Urbanização - memória justificativa. Beira: Empresa Moderna, 1951.

Costa, Vasco Vieira. Luanda - Cidade Satélite no 3. Concurso para a Obtenção do Diploma de Arquitecto [Luanda - Satellite City $\mathrm{n}^{\circ} 3$. Competition for Obtaining the Diploma of Architect. 1948]. Porto: Escola Superior de Belas Artes do Porto - Curso de Arquitectura, Departamento de Arquitectura da Faculdade de Engenharia de Luanda, 1984.

Curtis, William. Modern Architecture since 1900. London: Phaidon, 1999.

Ferguson, Francesca (ed.). S AM 03. Pancho Guedes - An Alternative Modernist. Basel: Christoph Merian Verlag/Swiss Architecture Museum, 2007.

Fry, Maxwell and Jane Drew. Tropical Architecture in Dry and Humid Zones. London: William Clowes and Sons, 1964.

Guedes, Pedro (ed.). Pancho Guedes: Vitruvius Mozambicanus. Lisboa: Museu Colecção Berardo, 2009.

Kahn, Louis I. "Monumentality." In Architecture Culture 1943- 1968 - A Documentary Anthology. Edited by Joan Ockman. New York: Rizzoli: Columbia Books of Architecture, 1993.

Le Corbusier. "L'Espace Indicible" [The Unspeakable Space.] L'Architecture d'Aujourd'hui $n^{\circ}$ special Art. Boulogne (January 1946): 9-17.

Le Corbusier. Salubra, Claviers de Couleur (2ème série) [Salubra, Color Keyboards (2nd series.)] Zurich: Éditions Salubra, 1959.

Magalhães, Ana. "Modern Architecture in África: open-air movie theathers." In Living Urban Modernity - DOCOMOMO International Conference XI. Mexico City: DOCOMOMO, 2010, 36.

Magalhães, Ana. Migrações do Moderno: Arquitectura na diáspora- Angola e Moçambique (1948-1975) [Migrations of the Modern: Architecture in the Diaspora - Angola and Mozambique (1948-1975).] PhD Dissertation. Universidade Lusíada de Lisboa, 2015.

Magalhães, Ana and Ines Gonçalves. Moderno Tropical, Arquitectura em Angola e Moçambique- 1948-1975 [Modern Tropical, Architecture in Angola and Mozambique- 1948-1975.] Lisboa: Edições Tinta da China, 2009.

Roth, Alfred (ed.). Zwei Wohnhauser von Le Corbusier and Pierre Jeanneret: Funf Punkte zu einer neuen Architektur [Two houses by Le Corbusier and Pierre Jeanneret: Five points to a new architecture.] Stuttgart: Akadem Verlag Dr. Fr. Wedekind and Co., 1927 and L'Architecture Vivante $\mathrm{n}^{\circ} 17,1927$. 
Sert, J. L., F. Léger and S. Giedion. "Nine Points on Monumentality." In Architecture Culture 1943- 1968 - A Documentary Anthology. Edited by Joan Ockman. New York: Rizzoli: Columbia Books of Architecture, 1993.

Sharp, Dennis. "Registering the Diaspora of Modern Architecture." In DOCOMOMO The Modern Movement in Architecture. Edited by Dennis Sharp and Catherine Cooke. Rotterdam: 010 Publishers, 2000.

Smith, Elisabeth A.T. Case Stdy Houses - The Complete CSH Program, 1945-1966. Taschen, 2009.

Távora, Fernando (ed.). Revista de Arquitectura [Architecture Magazine.] Porto: Faculdade de Arquitectura da Universidade do Porto, 1987.

Tinoco, João José, "Da Arquitectura Moderna em África e o seu panorama em Lourenço Marques" [Of Modern Architecture in Africa and its panorama in Lourenço Marques.] Capricórnio magazine, no. 2, (September 1958). 
